\title{
Assessing the Challenges and Opportunities of Pastoralists Sustainable Livelihoods: The Case of Yaballo Woreda of Borana Zone, Oromia
}

\author{
Abdi Aden Yasin ${ }^{1, *} \quad$ Sara Tadi ${ }^{2}$ \\ 1.Lecturer in Department of Public Administration and Development Management, Wolaita Sodo University, \\ P.O. Box 138, Wolaita Sodo, Ethiopia \\ 2.Sara Tadi Dubuluk Woreda Civil Service Bureau \\ * Author to whom correspondence should be addressed
}

\begin{abstract}
The main purpose of this study was to Assessing the Challenges and Opportunities of Pastoralists Sustainable Livelihoods: The Case of Yaballo Woreda of Borana Zone, Oromia Region. The study aimed at exploring the livelihood challenge facing by Borana pastoralists and potential for livelihood improvement. It is based on analysis of survey data generated from household level interviews in Yaballo Borana Zone southern Ethiopian Pastoralists'. To this end, interviews were carried out with local community leader and with selective local households. Moreover, scheduled questionnaires were carried out with the sample households and the FGDs' were organized with households in the selected Kebeles'. The study used mixed method research in data collections framed within the subject of sustainable livelihood framework for analyzing multifaceted relationships that exit between assets, livelihood strategies and outcome. The study found out that pastoralist are confronted by many livelihood risks such as lack of access to resources that are needed for their sustainability of their livelihood such as poor market conditions, lack of health services, and limited access to safe and clean water. Land has been the scarcest resource because investors and farmers own the huge part of village land.
\end{abstract}

Keywords: Pastoralism; Challenge; Opportunity; Sustainable livelihood; Yaballo; Borana; Ethiopia

DOI: $10.7176 / \mathrm{JESD} / 11-5-05$

Publication date:March $31^{\text {st }} 2020$

\subsection{Background of the Study}

This paper assesses the challenges and opportunities of pastoralists' sustainable livelihood the case of Yaballo Woreda in Borana Zone of Oromia Region. Borana is a predominantly pastoral zone located in the southern part of Ethiopia bordering Somali region in the East and North, Kenya in the South, Guji zone in the Northeast and SNNPR in the West. It is the largest of the 18 zones in Oromia regional state located in the arid and semi-arid southern lowlands. Borana pastoralists belong to the larger Oromo ethnic group who occupy parts of southern Ethiopia and northern Kenya. Under the present administrative structure, Borana mainly reside in Borana Zone. The study area covers a large proportion of the zone, particularly the arid and semi-arid Woredas of Yabello (USAID East Africa Resilience Learning Project, 2016).

Pastoralist societies in Ethiopia are facing more demands on their way of life this moment than at any previous time. Population growth, loss of herding lands to farmers, ranchers, wildlife parks, and urban growth, increased commoditization of the livestock economy, out-migration by poor pastoralists, and dislocations brought about by drought, famine and internal conflicts are increasing throughout the country.

As a matter of fact, Ethiopian pastoralists are responding to the social, political, and economic challenges with increased economic diversification including agro-pastoralism, wage labor, increased social and economic stratification, and market integration. These urban migration changes consequently result in increased and diminished nutrition for women and children (Jeremy L, 2016).

According to studies (e.g. Fratkin, 2001) indicate that these problems are intensified as international development programs encourage privatization and individuation of formerly communally held resources. With increasing level of investment by the Ethiopian government and the private sector due to the lucrative economic growth in the country, expansion to the pastoralist area looking for large and flat land size is manifested in Ethiopia (pastoral area comprises of about sixty percent of the country's landmass). Per capita livestock holdings and production are declining as a consequence of human population growth combined with heavy grazing of rangelands, induced mobility due to conflict and sedentarization. Encroachment into rangelands of agriculture and inedible plants, climate change, restrictions around livestock export and recurrent drought further contribute to the decline in pastoralism (Ibid).

Therefore, in the study area the researcher is facilitated by this problem to undertake this study such as the challenges of recurrent drought on sustainable livelihoods, the lack of facilitated access to infrastructure that will link to the central markets, the decline of financial capital, the traditional method knowledge rearing animal and management system, the lack of livestock insurance, poor animal health care and the challenge of environmental 
conservation and management system, which are very common among pastoral communities in Yaballo.

\subsection{Statement of the Problem}

In common with many other marginalized groups, pastoralists are highly vulnerable to misrepresentation or nonrepresentation within sustainable livelihood development processes. Suffering from negative effects of inappropriate modern development, and ignored or simply missed out of territory use and natural resource policy debate and formulation, the future sustainability of pastoralist livelihoods and pastoral domain hangs in the balance (Boku and Irwin, 2003).

This situation is common to pastoralists across Africa in general and Ethiopia in particular. Despite theoretical protection of pastoralist livelihoods rights under the constitution of the Federal Democratic Republic of Ethiopia (Government of Ethiopia, 1995), there is a catalogue of recent examples of inappropriate and contradictory policy applications. Such scenario clearly demonstrates the powerless position of pastoral communities in their own development and related affairs. According to the Enhanced Livelihoods in Southern Ethiopia project (part of USAID's broader Regional Enhanced Livelihoods in Pastoral Areas Programme), livelihoods for the Borana pastoralists of southern Ethiopia are under threat from repeated cycles of drought as well as other drivers of change, and marginalization from political and economic processes (ELMT/ELSE, 2008). Hence, the research tries to address the challenges and opportunities of pastoralists' sustainable livelihood the case of Yaballo Woreda in the context of Borana traditional pastoralist Oromia by raising the following research objective:

1. To know the major challenges facing the sustainable livelihoods of pastoralists' community in Yaballo Woreda?

2. To know the opportunity of sustainable livelihoods of pastoralists' community in Yaballo Woreda?

\subsection{Research Methodology \\ 1.4 Methodology of the study \\ 1.4.1. Research Approach}

According to Dawson (2002) and Kasley\& Kumar (1988) methodology is a philosophy or general principle, which guides a study. Hence, the research generally relies on qualitative and quantitative research. Qualitative research helps to undertake in-depth study through exploring attitudes, behaviors and experiences, and gathers information, which can best be described in words in describing situations, observed behaviors, people, events and interactions, etc. by using such methods or data collection instruments as key informants and focus group discussions (FGDs) through unstructured and semi-structured questionnaires. On the other hand quantitative research generates statistics and produces numerical data.

It also involves large-scale survey research. Therefore, to investigate the problem in different dimensions, using both qualitative and quantitative is very important. Hence, this study used both approaches.

\subsubsection{Sources of Data}

The study used both primary and secondary data sources. In order to achieve these objectives as well as analysis and explain the research scenario, primary sources were gathered through observation, interview, questionnaire, Focus Group Discussion. While, the Secondary data was collected from published and unpublished materials, which are available in the form of books, journal articles, policy briefs, proclamations, federal and regional constitutions, regulations, laws, organizational structures and performance reports.

\subsubsection{Method of Data Collection}

In achieving the objectives set, data was collected through different techniques. Scheduled Questionnaires were organized in to both open and close ended way, and then filled by data collectors. And, interviews were made With Kebele elder, Kebele health extensions and Kebele water management. And, also observation and photo capturing were used. At last, to deeply understand the issue under study the Focus Group Discussions was used with the group containing community leaders, local women, and rural households.

\subsubsection{Sampling Technique and Sample Size}

This study was employed multi-stage sampling technique in which both purposive and random sampling techniques will be applied. At the first stage, out of 13 Woreda of Borana zone, Yaballo Woreda would be selected purposively based on the diversity of livelihood opportunities available in the Woreda.

In the second stage, out of the total of 23 Kebele administrations of the Woreda four Kebeles, namely Dikalee, Utallo, Har-Weyyu and Dhadim would be purposively selected based on their livelihood opportunities. In the third stage, the households in the areas were selected based on their means of livelihood performance and physical accessibility. Therefore, the criterion of sample size selections was based on information which is obtains from the Borana zone Pastoralist Development and Administration offices and similarly Woreda office.

The total sample size that represents total population of study is determined by Yamane formula (Yamane, 1967). Since total population in the study area is known the researcher can use the Yamane formula for sample size determination. 
$\mathrm{N}$ - The total household population size

$$
n=N / 1+N(e)^{2}----------3.1
$$

$\mathrm{n}$ - The sample size

e - The acceptable sampling error

Here $n$, is the sample size needs to include the number of households. $N$ is the total household target population size which is 2190 and e is the acceptable sampling error which is 0.05 it means the researcher need to have $95 \%$ level of confidences in the study.

$$
n=2190 / 1+2190(0.05)^{2} \approx 338------3.2
$$

Hence, the sample size is fixed as 338 households, which is enough to meet the minimum requirement for the sampling.

The study adopted both qualitative and quantitative survey design as it aims at collecting information from respondents on assessing the challenges and opportunities of pastoralist's sustainable livelihoods: the case of Yaballo Woreda of Borana Zone, Oromia Region. Moreover, the study used mixed method research in data collections framed within the subject of sustainable livelihood framework for analyzing multifaceted relationships that exit between assets, livelihood strategies and outcome. Purposive sampling technique was employed by researcher because believes that the households likely have sufficient information and exposure on the topic under study. Out of the total 462 respondents, 338 sample respondents were selected.

\subsubsection{Method of Data analysis}

The study would be using simple descriptive statistics, which includes percentages, tables, as well as the qualitative description through the statement from interviews and questionnaires. Because descriptive statistics method of data analysis is more important and widely uses method due to its nature of simplicity and clarity to analyze, especially it is advisable for the beginner. In conducting the study, 338 questionnaires were distributed out of which 251 were returned and answered. With response rate of $251(74.3 \%)$ and $87(25.7 \%)$ was not returned.

\subsection{Description of the study areas}

The study is based on primary data generated through a household survey undertaken in case of Yaballo Borana pastoral area, southern Ethiopia. Yaballo is one of the 13th districts of Borana zone located at center of the zone in Oromia region and located at $570 \mathrm{~km}$ south of Addis Ababa. The relative location of the Yaballo Woreda at the North Dugda Dawa Woreda, the South Dubuluk Woreda, the East Arero Woreda and the West Telltale Woreda.

The name Yaballo comes from Yaa'a Bal'aa which means large ritual settlement of Borana Oromo's Gada system. However, the total land area of the Woreda is about $5909 \mathrm{~km} 2$ of which $31 \mathrm{~km} 2$ is cultivated, $338 \mathrm{~km} 2$ is covered with forest, $681 \mathrm{~km} 2$ is bush and shrubs, and $4900 \mathrm{~km} 2$ is wood land (WBISPP, 2003). Livestock production is the major means of livelihood in the study area and contributes to the subsistence requirement of the population, among other, in terms of milk, and milk products and meat, particularly from small ruminants.

\subsection{Status of sustainable livelihoods of the study areas}

The Famine Early Warning Systems Network (FEWSNET) has categorized Yaballo Woreda of Borana zone in Southern Ethiopia in an 'emergency' phase vis-a-vis acute food insecurity. On foot of this, an interagency mission completed an assessment of the humanitarian needs and priorities of the affected populations of Yaballo Woreda Borana Zone, Oromia state, Ethiopia from July 26th-29th 2011.

However, the evaluation team was comprised of 14 international, national, and local agencies complemented by representatives from relevant zone and Woreda government offices. Organizations participating in the assessment were: CAFOD/Trócaire/SCIAF Joint Programme; Help Age International; ACF; Plan International; ACORD; CARE; GOAL; GPDI; AFD; CIFA; Awassa Diocese; SOS Sahel; CISP; CISO; and representatives from the local government.

In addition the team visited eight districts of Southern Borana Zone (Yaballo, Telltale, Miyo, Moyale, Dire, Dhas, Arero, and Dillo) and used rapid assessments, focus groups, and interviews with communities and local Woreda and zone officials to gather primary and secondary data. Throughout districts food insecurity, severe water shortages, and livestock depletion among communities are omnipresent in Borana Zone. The degree to which each district is affected diverges only minimally although Yaballo district is perceptibly less affected. People are spending 3-5 hrs per day accessing water, walking on average 3-5 hours.

Access to food is now a priority concern for people. However, the utility (purchasing power) of cash has diminished. Markets are struggling to supply essentials (maize, oil pulses) creating inflationary pressures on available goods. Consequently, Secondary data identifies increasing cases of malnutrition with rising recorded cases of measles, acute watery diarrhea and malaria. Vulnerable groups - women and child headed households, the elderly, and the people with disability and illness- are uniformly affected. There have been isolated reports of theft and increased inter-communal violence but there is no evidence of a systematic heightened risk to any particular vulnerable group. 


\subsubsection{Map of the Yaballo District}

Map of Yaballo district that shows all PAs in the district and its capital towns is illustrated in the given below.

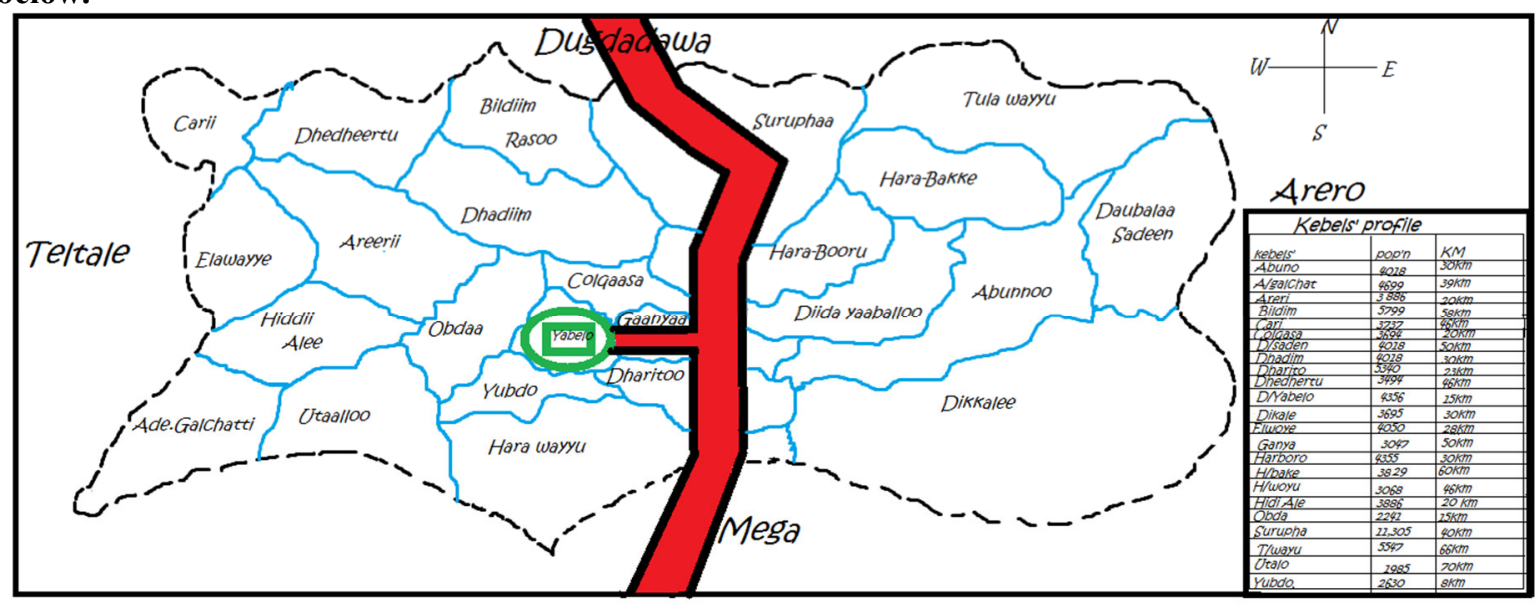

Figure 1: the Topographical map of Yaballo District: Source, Survey result, 2019.

\section{Result and Discussions}

\subsection{Demographic Characteristics of Sample Households}

The need to analyze the demographical aspect in assessing the challenges and prospects of rural water supply and sanitation is due to the fact that, in pastoral areas the demographic aspect has its own contribution towards the share of the burden of absence of water, and the impact of the absence of sanitary practice.

Table 4.1: Distribution of Sex of Sample Households $(n=338)$

\begin{tabular}{|l|l|l|}
\hline Sex of respondents' & Frequency & Percentage \\
\hline Female & 172 & 64.2 \\
\hline Male & 96 & 35.8 \\
\hline Total & $\mathbf{2 6 8}$ & $\mathbf{1 0 0}$ \\
\hline
\end{tabular}

\section{Source: Survey Result, 2019}

The table 4.1, the scheduled questionnaires reached males constituting 96 (35.8\%) of the total sample, and females constituting $172(64.2 \%)$ of the total sample selected in all the four Kebeles. From this result it is possible to infer that the results of the household survey would be more reliable, because it has been observed and confirmed by the household survey and focus group discussions, that female took the burden of livelihoods than male. Meanwhile, it is female who suffer the burden of livelihoods in pastoralist communities in Borana so that it has its own implication to take majority of their number in the study of this kind. And, also, they were, in a better position to give accurate information than male who was not directly involved in the activity.

Table 4.2:- Percentage Distribution of Age of Sample Households $(n=338)$

\begin{tabular}{|l|l|l|}
\hline Respondent & Frequency & Percentage \\
\hline $20-35$ & 32 & 11.94 \\
\hline $36-45$ & 139 & 51.87 \\
\hline $46-65$ & 70 & 26.12 \\
\hline Above 66 & 27 & 10.07 \\
\hline Total & $\mathbf{2 6 8}$ & $\mathbf{1 0 0}$ \\
\hline
\end{tabular}

Table 4.2 shows that about $89.93 \%$ of respondents were in the economically productive age. While, the left $27(10.07 \%)$ are economically under non-productive age. From this it is possible to understand that data was gathered from the productive age group and indeed people of this age group are those expected to take parts in the processes of challenges and opportunity of sustainable pastoralist livelihood in Borana pastoralist communities.

Table 4.4:- Percentage Distribution of Occupation of Sample Households $(n=338)$

\begin{tabular}{|l|l|l|}
\hline \multicolumn{1}{|c|}{ Respondent } & Frequency & Percentage \\
\hline Agro pastoral & 0 & \\
\hline Petty trade & 21 & 7.84 \\
\hline Pastoralist & 203 & 75.75 \\
\hline Total & $\mathbf{2 6 8}$ & $\mathbf{1 0 0}$ \\
\hline
\end{tabular}

Source: Survey Result, 2019 
Table 4.4 Indicates that the sample households have different occupations. These include agro pastoralists 0 $(0 \%)$, pastoralists constituting $203(75.75 \%)$, petty trade 21 (7.84) and other constituting 44 (16.41\%). Moreover, from the table it is possible to infer that the majority of respondents are pastoralist.

In general, from the above table we can possible to say that pastoralists believe that the aids from NGOs are positive. They prefer the help from NGOs that are more durable, such as well and pond construction. They also believe that re-stocking programs are important because those helped them to development livestock number after drought. In addition, the opportunity to earn cash is highly valued, since there are few chances to get cash except selling livestock. However, it is possible to point out that food aid made some pastoralists dependent on such aid, and are not working hard to secure their livelihoods. According to interview conducted with Kebele elder "NGOs really did us big favors. They constructed wells and ponds for us. It is convenient to have water points in close proximity to our village." "Re-stocking is helpful for me. I lost almost all of my livestock during the severe drought in 2011.

The NGO gave me several calves, which enables me to develop my herd." "We prefer aids that are durable, something that can last for a long period. The ponds and wells are good for us. We like grains as food aid, but they cannot solve our long-term problem. In addition, I see some people are getting dependent on the food aid, thus not working hard on themselves to secure their livelihoods." "The cash for labor projects are good for us. We hope more NGOs would come to our village and organize labors to clear bushes or dig ponds."
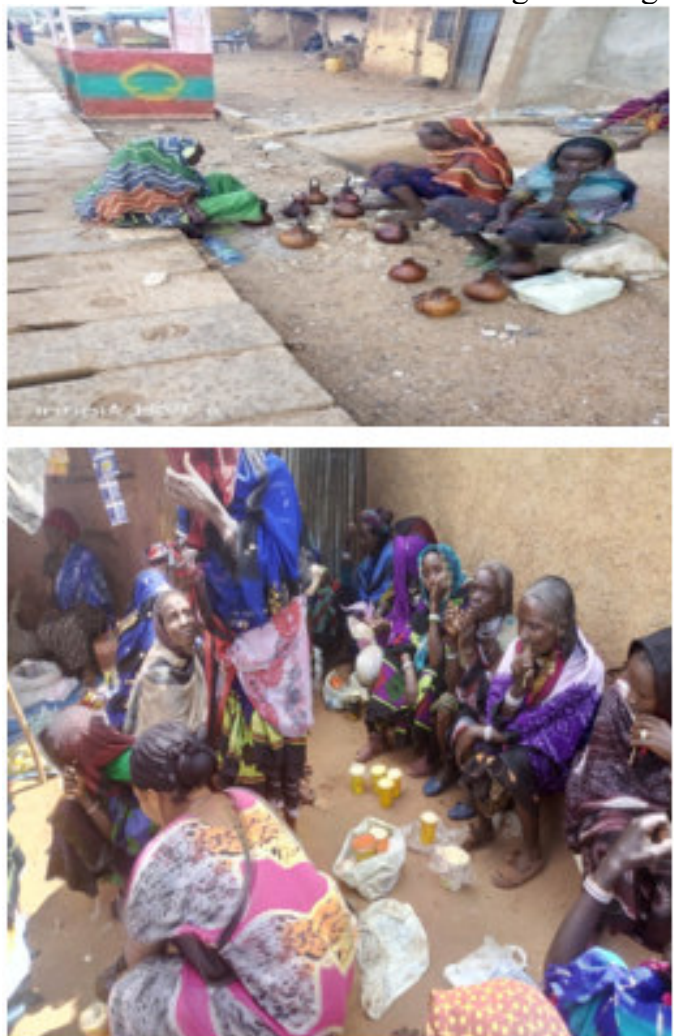
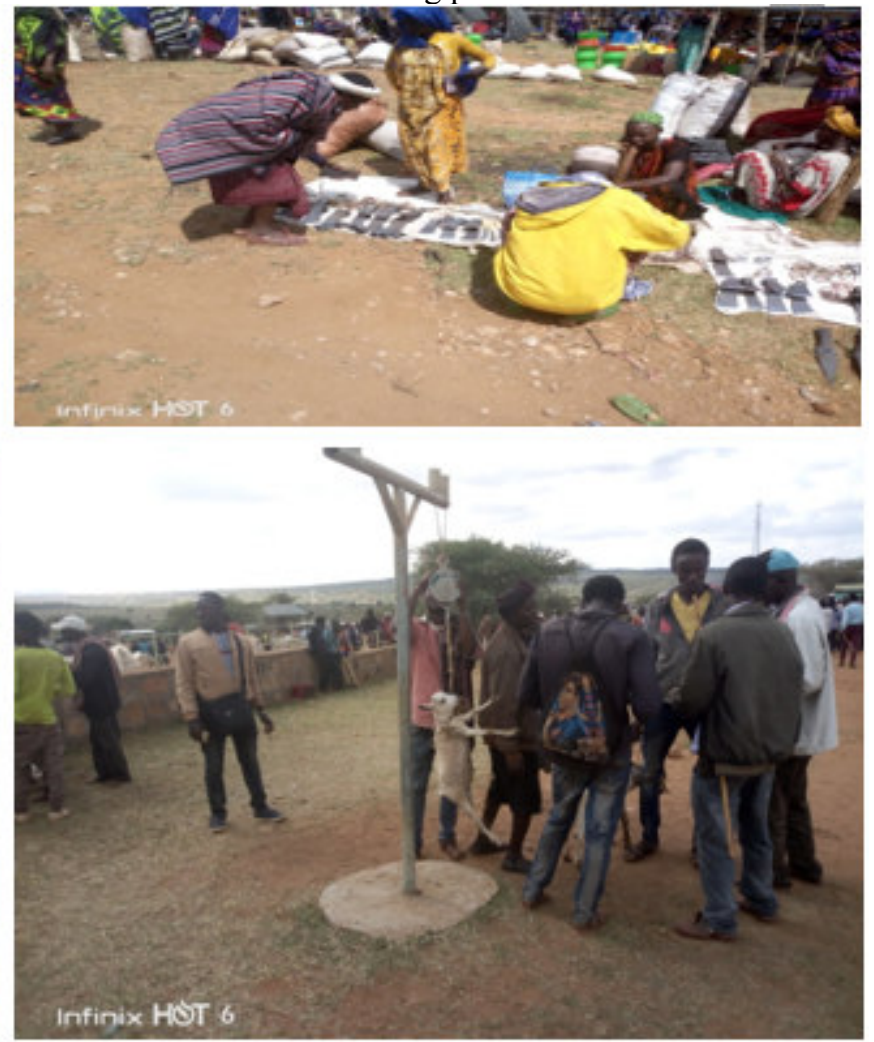

Figure 2: Pastoralist exercising petty trade on Market day: Source: Survey result, 2019

Gadaa as a system of governance embodies several institutions which manifest themselves in an overall socioeconomic and political culture. Gadaa has been an egalitarian and democratic socio-political and cultural system of governance, which has also been practiced among all Oromo branches and other Cushitic peoples, like the Sidama, the Konso and the Gedeo (Abdurahman A, 2019). 


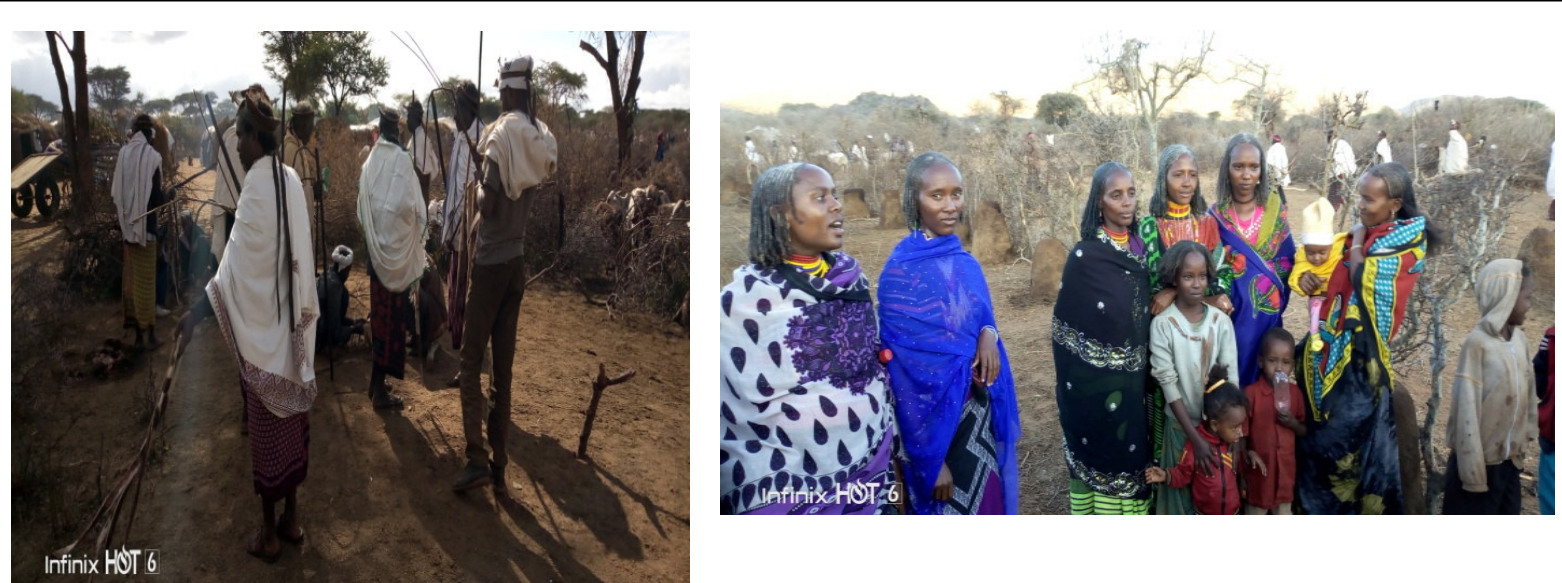

Figure 3: Shows the Gadamojji settlement camps or Galma: Source: survey result, 2019

However, according to interview conducted with religious elders Gada system is the main social structure which is a complex, elaborate and all embracing social institution of Borana pastoral communities. In addition this system generally deals with the relations within and between the generations. And more fundamentally, it is about how the Borana should live their lives. The use of existing grazing lands and water resources, and mobility of people and livestock in normal or in periods of disaster is governed by the Gada system. It also plays a large role in political affairs and conflict management and resolution.

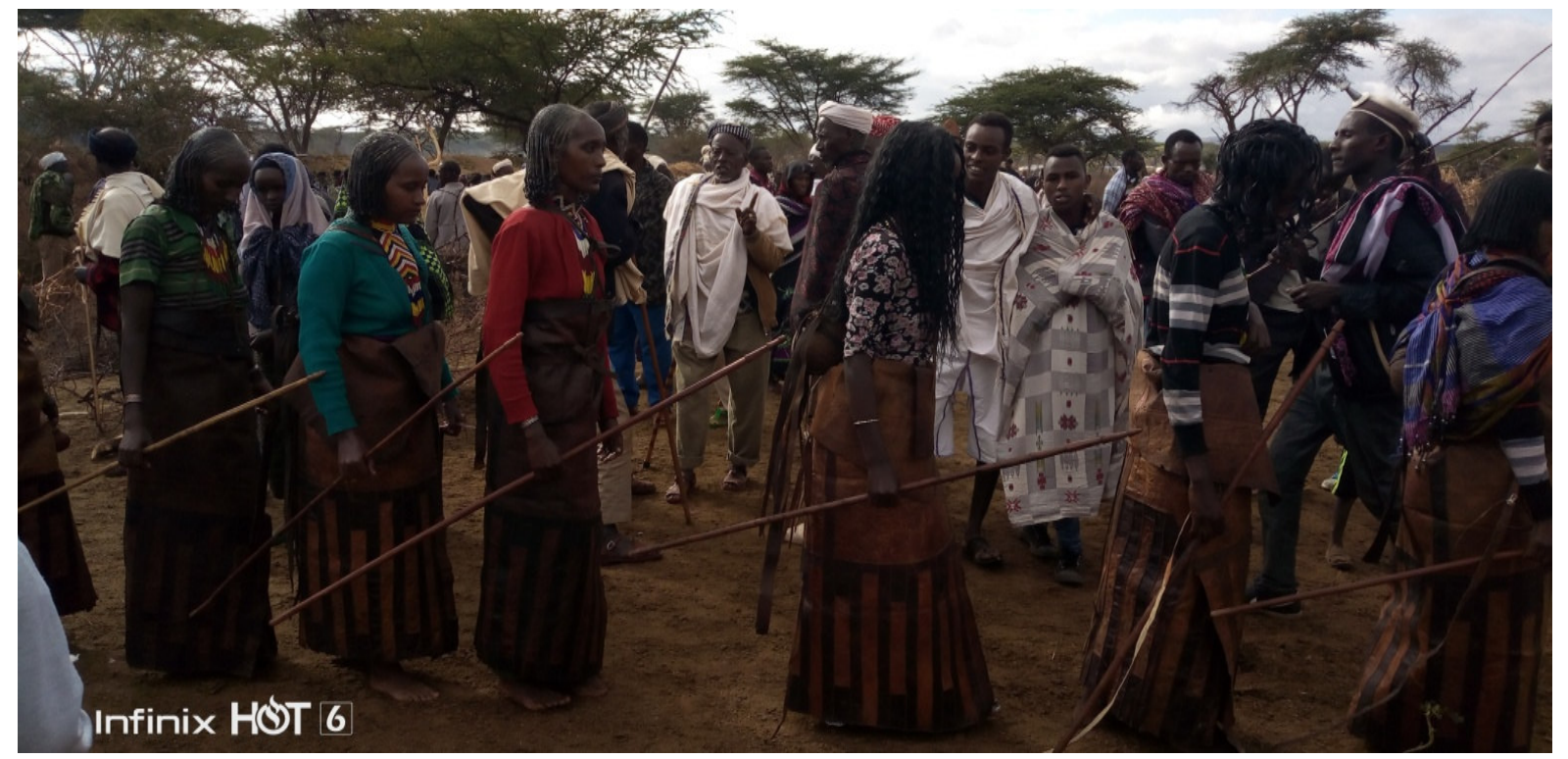

Figure 4: The Gadamojji celebration ceremony: Source: Survey result, 2019

The Borana people have rich traditions and values that pass from generation to generation. These tradition include the ceremonies they perform to signify some of the important aspect of their lives. These ceremonies not only help in the continuation of cultural values from generation to generation but also a commemoration of significant happenings. There are various types of ceremonies and rituals they perform. According to focus group discussion conducted with religious elder in the tradition of this ancient culture, the Gadamojji represents a significant period in the lives of all Borana people. However, the event Gadamojji is celebrated every eight years according to the lunar calendar and with its ceremonial activities and political values, its importance is highly regarded by tribal members. The Borana also name a significant member of the tribe as Gadamojji, a very high position for an elder.

\subsection{Challenges and Opportunities}

\subsection{Livelihood Challenges Faced By Borana Pastoralist Communities}

The researcher was also interested to know the main livelihood challenges faced by the pastoralist societies at Dikale, Hara-Weyu, Dadim and Hutalo ward in the four selected Kebele. The following section presents these livelihood challenges

\subsubsection{Access to reliable and affordable healthcare}

Due to intense competition in healthcare, the healthcare industry, as the largest contributor to the service industry, 
is facing enormous challenges and developing an effective sustainable healthcare system has become a difficult task. Therefore, effective and sustainable healthcare systems are key to providing quality healthcare at a low cost, with large population coverage and effective disease management. However, cost efficiency and healthcare effectiveness cannot be achieved at the same time and researchers indicated a trade-off between the increase in efficiency and effective healthcare system. Healthcare effectiveness shows the potential of the healthcare system to achieve maximum healthcare output (lo Storto, C.; Goncharuk, A.G, 2017)

Table 1: * Do you have veterinary service in your Kebeles

\begin{tabular}{|c|c|c|c|c|c|}
\hline \multirow[t]{3}{*}{ No } & \multirow{3}{*}{\multicolumn{2}{|c|}{ Name of Kebeles }} & \multirow{2}{*}{\multicolumn{2}{|c|}{$\begin{array}{l}\text { Do you have veterinary service in your } \\
\text { Kebeles? }\end{array}$}} & \multirow[t]{2}{*}{ Total } \\
\hline & & & & & \\
\hline & & & Yes & No & \\
\hline 1. & Dikale & $\begin{array}{l}\text { Count } \\
\% \text { of Total }\end{array}$ & $\begin{array}{c}6 \\
6.6\end{array}$ & $\begin{array}{c}85 \\
93.4\end{array}$ & $\begin{array}{l}91 \\
100\end{array}$ \\
\hline 2. & Hara-Weyyu & $\begin{array}{c}\text { Count } \\
\% \text { of Total }\end{array}$ & $\begin{array}{c}2 \\
2.7 \\
\end{array}$ & $\begin{array}{r}72 \\
97.3 \\
\end{array}$ & $\begin{array}{c}74 \\
100 \\
\end{array}$ \\
\hline 3. & Dadim & $\begin{array}{l}\text { Count } \\
\% \text { of Total }\end{array}$ & $\begin{array}{c}4 \\
3.8\end{array}$ & $\begin{array}{c}101 \\
96.2\end{array}$ & $\begin{array}{l}105 \\
100\end{array}$ \\
\hline 4. & Hutalo & $\begin{array}{c}\text { Count } \\
\% \text { of Total }\end{array}$ & $\begin{array}{c}3 \\
4.41\end{array}$ & $\begin{array}{c}44 \\
64.70\end{array}$ & $\begin{array}{l}47 \\
69.11\end{array}$ \\
\hline \multicolumn{3}{|c|}{ Total } & 4.38 & 87.9 & 92.28 \\
\hline
\end{tabular}

This study found that accesses to veterinary service in all four Kebeles are limited. Majority of the respondents had difficulties in accessing to veterinary services. From the above Table, it might be shown that $6.6 \%$ of respondents from Dikale Kebele had been said an access to veterinary services as compared to $93.4 \%$ that had no access to veterinary service in their local areas. Conversely, $2.7 \%$ of respondents from Hara-weyyu Kebele agreed to have access to veterinary service and $97.3 \%$ of the respondents disagree to have access to veterinary services. So as to understand from the above table the problem of animal health care services were not difference from the four Kebele at selected of study area but except few percent of respondents answered in some sites variations. However, posts are lacked a sufficient drugs and also lack of veterinary professional service. For these reasons, the death of Borana pastoralists' livestock increased from time to time especially sheep and camels were suffering repeatedly. Besides, for the case of animal health care problem the livestock market prices would be low down and the pastoralists' household annual income was decreased.

\subsubsection{Access to reliable market}

An essential pre-requisite for access to adequate and reliable property market information to improve valuation practice in Ethiopia, boost investor confidence and stimulate investment activities is a need for a conceptual and practical shift in the way market information is collected, managed, provided and accessed. However, a suitable and pragmatic prescription will, in part, require identification and understanding of existing market information sources and the reliability of the information produced by the sources (Kwasi G \& Frank G, 2017). As well as the information collected from FGDs and the econometric output reveals that in adequate market at proximate place influences their production system and reduces their opportunities to diversify livelihood system.
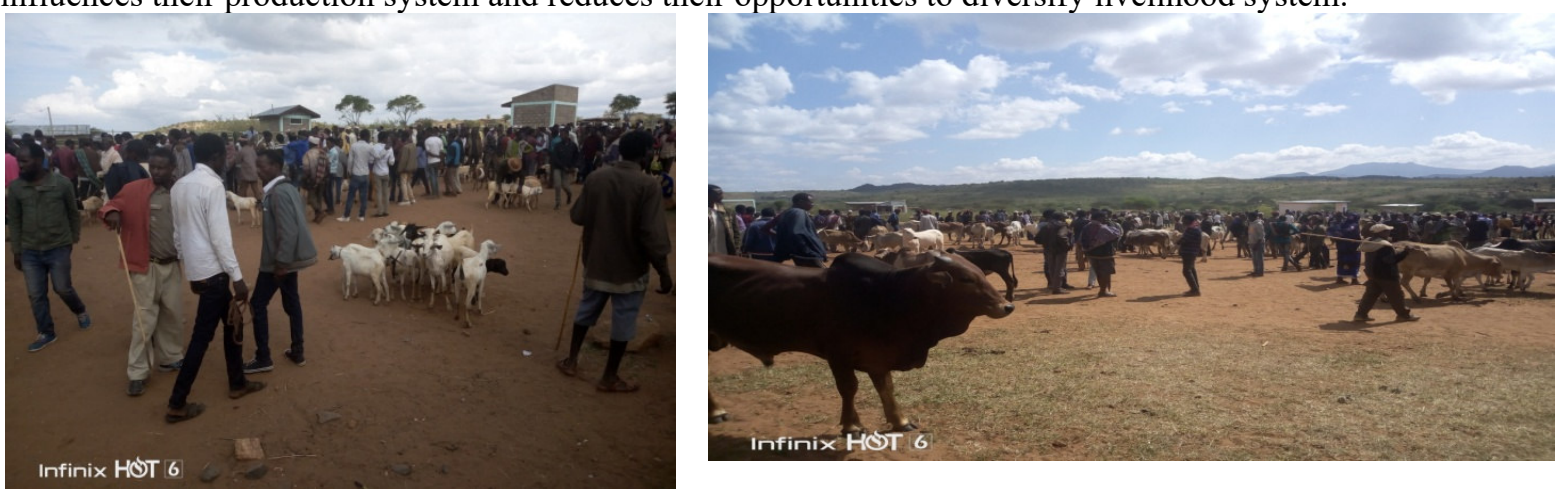

Figure 5: Animals market place: Source: Survey result, 2019 


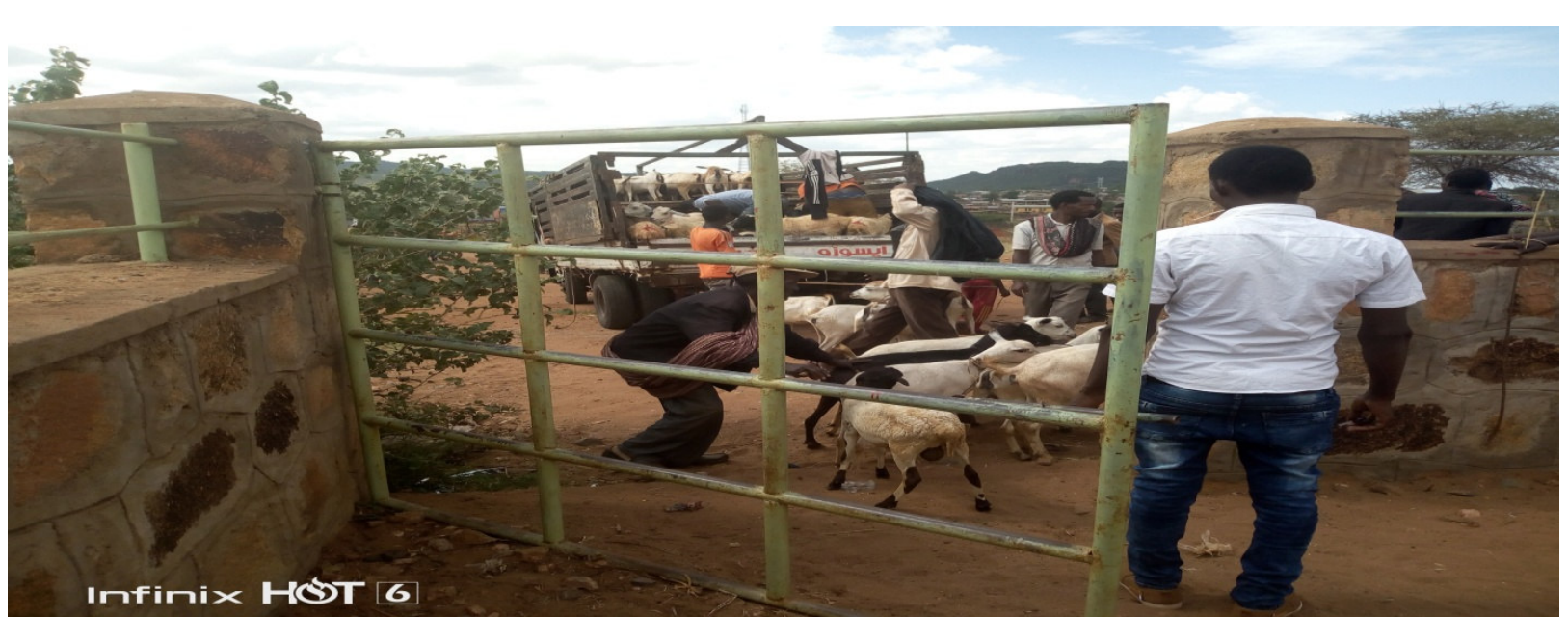

Figure 6: A Lories transporting sheep's into middle or exporting market place: Source: Survey result, 2019 4.3.3. Access to financial services

One of the major challenges faced globally that is impeding human and economic development is poverty (Asongu, 2013; Baumann, 2001; Chibba, 2009; Tavanti, 2013). With the levels of poverty, inequality, and social-exclusion on the rise, calls to close this gap are also becoming louder. Such calls have been made, for example, by Lagarde (2014) the UNDP (2012) and von Burgsdorff (2012).

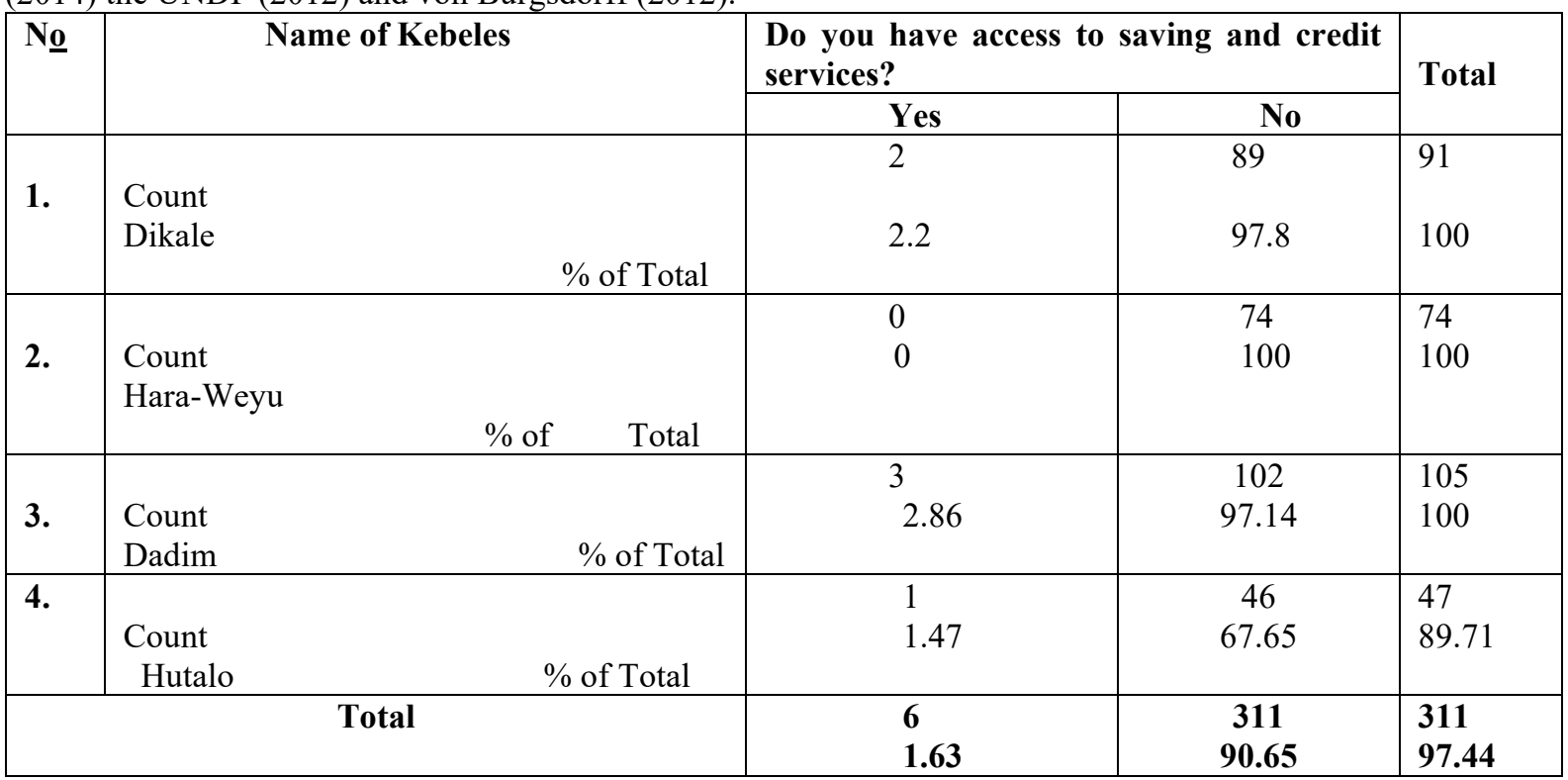

As regards to access to financial services such as bank loans and micro credits, all respondents (97.8\%) reported that they do not have access to financial services to boost their capital (restocking). One of the reasons for not having such an access being that they fail to meet the conditions set by the banks. Many argued that, "they are lacking financial knowledge and physical asset (land) to use as collateral as a requirement to secure bank loans". Whatsoever, this study also found out that most of the respondents lacked formal education and as a result it was difficult for the financial institutions to provide loans to them. Lack of financial capital boost has made it hard for pastoralists to intensify productivity.

\subsubsection{Access to clean and safe water for domestic use}

Clean and safe drinking water is vital for human health and can reduce the burden of common illnesses, such as diarrheal disease, especially in young children. Unfortunately, in 2010, it was estimated that 1.8 billion people globally drank water that was not safe [Hutton G; Chase C, 2016]. This scenario is most common in developing countries, and the problem is exacerbated in rural areas [Ibid]. Significant amounts of time are spent by adults and school children upon water abstraction from various sources [Brookes JD, 2017; WWAP, 2015]. It is estimated that, in developing countries, women (64\%) and girls (8\%) spend billions of hours a year collecting water [Hutton $\mathrm{G}, 2016]$. The erratic supply of safe drinking and domestic water often affects good hygiene practices. In most developing countries of the world, inadequate supplies of drinking water can contribute to the underage death of children in the region [Ezeh OK; Agho KE; Dibley MJ; Hall J; Diouf K; Tabatabai P; Rudolph J; Marx M, 2014]. 
Table 4: Village name * do you have reliable access to clean and safe water for domestic use?

\begin{tabular}{|c|c|c|c|c|c|}
\hline \multirow[t]{2}{*}{ No } & \multirow[t]{2}{*}{ Name of Kebeles } & & \multicolumn{2}{|c|}{$\begin{array}{l}\text { Do you have reliable access } \\
\text { to clean and safe water for } \\
\text { domestic use? }\end{array}$} & \multirow[t]{2}{*}{ Total } \\
\hline & & & Yes & No & \\
\hline \multirow[t]{2}{*}{1.} & & Count & 4 & 87 & 91 \\
\hline & Dikale & $\%$ of Total & 4.5 & 95.6 & 100 \\
\hline \multirow[t]{2}{*}{2.} & & Count & & & \\
\hline & Hara-Weyu & $\%$ of Total & 4.05 & 95.95 & 100 \\
\hline 3. & Dadim & $\begin{array}{r}\text { Count } \\
\% \text { of Total }\end{array}$ & $\begin{array}{c}2 \\
1.9\end{array}$ & $\begin{array}{c}103 \\
98.1\end{array}$ & $\begin{array}{l}105 \\
100\end{array}$ \\
\hline 4. & $\begin{array}{l}\text { Hutalo } \\
\text { Total }\end{array}$ & $\begin{array}{r}\text { Count } \\
\% \text { of Total }\end{array}$ & $\begin{array}{c}6 \\
8.82\end{array}$ & $\begin{array}{c}41 \\
60.29\end{array}$ & $\begin{array}{l}47 \\
70\end{array}$ \\
\hline
\end{tabular}

This study found that water is very scarce resource in the area understudy. All respondents complained about the challenge in accessing clean and safe water for domestic use. Only $4.5 \%$ from Dikale and $4.05 \%$ Hara-weyu had an access to clean and safe water for domestic use compared to $98.1 \%$ of respondents from Dadim who had no access to clean and safe water for domestic use. Generally $60.29 \%$ of respondents in all four villages had no access to clean and safe water, $8.82 \%$ agree to have access to clean and safe water for domestic use. They went on to say that sometimes they had to walk for more than an hour to get to water wells.

Too these much many respondents argued that the problem was worsened by prolonged drought and shortage of rain. In terms of gender, the study found out that the problem of water shortage affects women and children more because they are the ones who look for it at household level for domestic use. Consequently, in the study area called "Har-Weyuu" indicating water is the most scarce resources in pastoralist community, as their life is highly depend on livestock production, water is the determinant factor for the livelihood of the pastoralist, water is highly scarce in the area, searching water for their animals and human consumption is the major duty of the community, unavailability of water in the nearest place force them to travel long distance and weak animals exposed to more challenging situation.
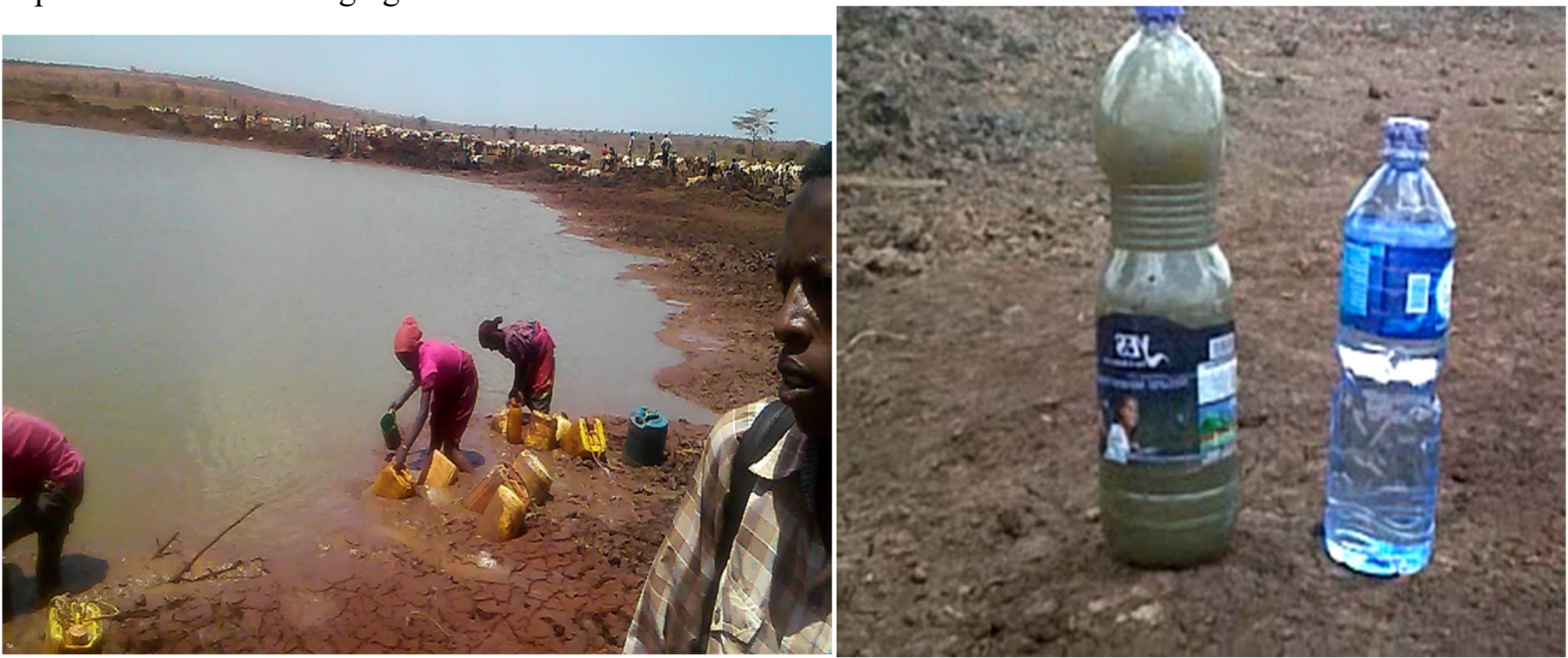

Figure 7: Water source of sample household's

\subsection{Household Asset and Resources Management}

Livestock and livestock products provide about 10\% of Ethiopia's foreign exchange earnings, with hides and skins constituting about $90 \%$ of this. Markets are becoming increasingly pivotal for pastoral household food security. In the severe and widespread drought of 2000, outside observers concluded that, except in extreme pockets of isolation or insecurity, there was no significant problem of food availability, and if satisfactory ways could be 
found of increasing pastoralists' cash income, there would be no separate food crisis' (Sandford and Habtu, 2000).

\begin{tabular}{|l|l|l|l|l|}
\hline \multicolumn{7}{|c|}{ Has your household been received remittance for the last ten years? } \\
\hline No & Household remittance & category & frequency & Percentage \\
\hline \multirow{2}{*}{1.} & \multirow{2}{*}{$\begin{array}{l}\text { Has your household been received } \\
\text { remittance for the last ten years? }\end{array}$} & Yes & 38 & $42 \%$ \\
\cline { 3 - 5 } & & No & 52 & $58 \%$ \\
\cline { 3 - 5 } & No answer & - & - \\
\cline { 2 - 4 } & Total & $\mathbf{9 0}$ & $\mathbf{1 0 0 \%}$ \\
\hline
\end{tabular}

Source own survey, 2019

From the above tables it is possible to say that household not receiving remittance. Borana is the poorest of all Ethiopia's rural regions, with the lowest poverty headcount $-58 \%$ of household not receiving any remittance, but relying on NGOs and government on food for aids. In addition, we can easily predict from table above those household not received any remittance face financial difficulties. Another expense that is often foregone in times of economic difficulty is health care.

This is particularly true in rural areas, where the cost of seeking health care is compounded by the costs of travelling to the nearest health care facility and often paying for accommodation costs for the patient and/or their relatives while seeking treatment. They had insufficient cash to pay for medical expenses.

Whatsoever, $42 \%$ of this relative wealth derives remittance from the region's high levels of livestock product exports and imports of consumer goods for resale. However, the economy is more closely integrated with the business than other parts of Ethiopia, including Addis Ababa. However, Livestock-dominated livelihoods and dependence on cross-border trade are sources of wealth, but also of vulnerability.

According to focus group discussion conducted with Kebele committee migration is common especially among the landless youth, who exclusively depended on the land now transferred for investment. This group of the society migrates to other areas in search of jobs to make a living for themselves as well as their dependent families back home. Many of them work as hired laborers in distant towns and cities while others set up their own businesses and send back remittances to their families.

\begin{tabular}{|l|l|l|l|l|}
\hline No & livestock own & category & frequency & Percentage \\
\hline \multirow{2}{*}{$\mathbf{*}$} & Do you family own livestock? & Yes & 22 & $24 \%$ \\
\cline { 3 - 5 } & & No & 68 & $76 \%$ \\
\cline { 3 - 5 } & No answer & - & - \\
\cline { 3 - 5 } & Total & $\mathbf{9 0}$ & $\mathbf{1 0 0 \%}$ \\
\hline
\end{tabular}

As shown from above table $76 \%$ of household are the destitute also relies on social support from the community as well as food aid from the governments and NGOs. These accounts are means of earning for these people. In addition to this both women and young men involve in working outside the community to generate income. It was also indicated that this type of activities were also a response to the poverty caused by drought.

However, in the study areas income generation through production of livestock and crop is under the control of men. Women also contribute to household income through involvement in productive activities such as livestock and crop production, trading and wage work. Whatsoever, in the study areas the major source of income for the rich households is livestock. Cash income sources for the rich households include sales of livestock (cattle, goats, and camels), milk, and butter.

2. Based on question No 1, what types of livestock's the households own?

\begin{tabular}{|l|l|l|}
\hline Types of livestock & Frequency & \% \\
\hline Cattles & 85 & 31.72 \\
\hline Goats & 70 & 26.12 \\
\hline Sheep's & 57 & 21.27 \\
\hline Camel & 44 & 16.42 \\
\hline Donkey & 12 & 4.48 \\
\hline Total & $\mathbf{2 6 8}$ & $\mathbf{1 0 0}$ \\
\hline
\end{tabular}

(Source own survey, 2019)

On the other hand, the rich households own up to $85(31.72 \%)$ cattle, $44(16.42 \%)$ camels, $70(26.12 \%)$ goats, $12(4.48 \%)$ donkeys; and 57(21.27\%) sheep's and whereas, Camels are introduced in the production system and only $16.42 \%$ of the households own them. 

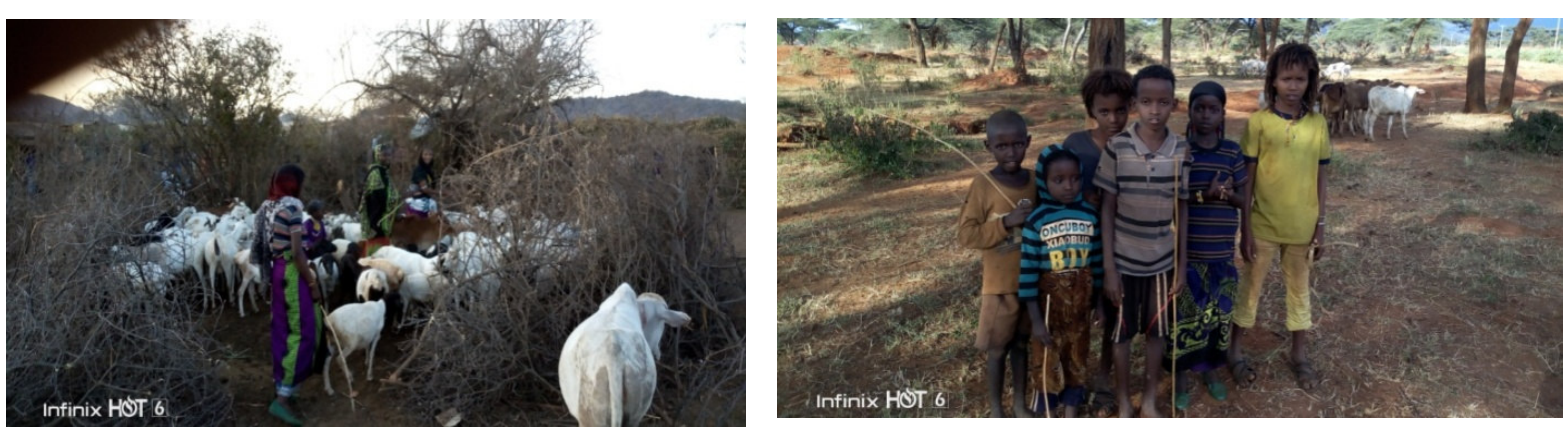

Figure 8: A young pastoralist children looking after the calves

\begin{tabular}{|l|l|l|}
\hline \multicolumn{3}{|c|}{ Who is decision maker on your household's livestock management? } \\
\hline Household decision maker & frequency & Percentage \\
\hline Men & 42 & 15.67 \\
\hline Women & 158 & 58.95 \\
\hline Jointly & 68 & 25.37 \\
\hline Total & $\mathbf{2 6 8}$ & $\mathbf{1 0 0}$ \\
\hline
\end{tabular}

The Oromo people, like the other peoples and nationalities of the country, have immense tangible and intangible heritages which have been created over centuries in the interactions of the people with natural and social environments and which stand as the manifestations of the identity of the people.They share common language, history and descent, and once shared common political, religious and legal institutions. What makes the region even more special is that these cultural and natural resources are managed within an ancient traditional governance system, the Gada system, which is rich in democratic principles and with its roots spread throughout the Oromia area ( Oromia Culture and Tourism Bureau, 2017)

Based on the above tables we can easily say that the $58.95 \%$ of decision making power on household livestock management is vested in the hands of women.

According to key informant interview in all Kebele women perceptions of their role in livestock management includes milking, milk processing, sewing and smoking of milk containers, milk storage and sale. In addition to this fodder collection was considered one of the hardest tasks, listed by women, only fetching water by jerry can was considered more arduous. 'From the morning to the evening' she has to go and search for grass in order to feed her young stock.

\subsection{Land ownership between pastoralists and agro-pastoralists and farmers}

Pastoralist land use and the entailing property and use rights are highly complex. They consist of an assemblage of different rights regarding access, management and control each encompassing different aspects of 'property'. 'Access' includes the right to withdrawal, i.e. the right to use the land as a pasture; 'management' means the right to decide about the use made and to make improvements; 'control' in turn would include the right to decide about who may use the resource; but also absolute property as such. Accordingly, different rights on the same piece of land can be vested in different communities. This leads to a complex set of overlapping rights that are continuously contested and renegotiated' (Kaderi N, 2017).

\begin{tabular}{|l|l|l|l|}
\hline \multirow{2}{*}{ o } & \multicolumn{3}{|c|}{ Who owns more land? } \\
\cline { 2 - 4 } & Ownership of land & Frequency & Percentage \\
\hline 1. & Pastoralists & 125 & 46.64 \\
\hline 2. & Agro-pastoralists & 95 & 35.44 \\
\hline 3. & Farmers & 48 & 17.91 \\
\hline & Total & $\mathbf{2 6 8}$ & $\mathbf{1 0 0}$ \\
\hline
\end{tabular}

As the above table show that 95(35.44\%) Agro-pastoralists: households belonging to this group largely depend on both crop and livestock; as expected, agro-pastoralist households are relatively represented within this cluster; Pastoralists 125(46.64\% households): households whose livelihood is mainly from livestock (; $46.64 \%$ of them live in rural area.

According to focus group discussions conducted with one of religious elder of Hara-weyu he said that "All pastoralists are rich; alternatively, all pastoralists are poor and food insecure." Farmers or urban people, whose main investment may be a single cow or three sheep, see herders with what seem like large herds, and may think that they are immensely rich. To this ends, he said the fact that the herd is working capital; animals cannot simply be sold at will if the pastoral enterprise is to survive and prosper.

Additionally, he said that at the opposite end of the scale, the droughts and famines of the last three decades have created a media image of pastoralists as destitute, too poor to survive other than on food aid. Neither picture 
is wholly true. Within pastoral society, like any other, there are rich and poor households. Recent economic events, especially famines from which some people benefit, have created a few rich households and many poor ones in most pastoral societies.

\section{Conclusion}

Based on table1 it is possible to conclude that respondents perceived drought differently. Most $96(35.8 \%)$ of male total sample household selected in all the four Kebeles respondents perceived drought to be a deficiency of rainfall for a season or more. However, they understood it to be depletion of water and pasture, they perceived it to be period of hunger and destitution and understood drought to be an act of God (Table 1). Traditional sources i.e. use of rainmakers and seers, was the only source of information on weather forecast relied on by the pastoralists in the study area.

According to interview conducted with one of Kebele elder loss and paying for food aid in a drought-affected 15 of his cattle. He decides to sell 1 bull as he knows that with the income, he can buy enough maize to feed his family of six people for two months. His decision is based on the fact that he can sell a thin bull for Ethiopian birr 440 (US\$50), and with that money, can buy 200kg of maize (cost Ethiopian birr 160/100kg). Also, he knows that each person will eat around $0.5 \mathrm{~kg}$ of maize a day and so for two months, he'll need $180 \mathrm{~kg}$ of maize for the family.

It is possible to conclude that the majority of land was owned by pastoralist, the reason in order to review the possible impacts of rangeland enclosures in Borana supported by NGOs, it is useful to recognize that different types of enclosures already existed before NGO activities, with various forms of local management, control and access. However, Borana pastoralists' traditional enclosures were called seera yabbii (literally 'protected grazing for calves'). They were relatively small, around 10 hectares or less, and had a very specific purpose - to conserve pasture or put aside a section of the rangeland for milking cows, calves and sick animals during the dry season/ times of drought.

In addition, the size varied depending on the anticipated rainy season, the number of young or sick calves anticipated in the coming year for a given olla5 and the local forage conditions. For example, if drought was expected, the seera yabbii would be bigger, if good rain was expected; the seera yabbii would be smaller. Seera yabbii were established on relatively productive land and were not fenced.6 they have mostly been replaced through the introduction of kallos, which are larger, fenced enclosures and which have different functions.

The most commonly used definition of "access" is defined as having a source of safe water within 1 kilometer of the dwelling. It is estimated that in 2015, 663 million people still lacked access to "improved" drinking water sources. Improved sources are those deemed to be relatively protected from contamination and, therefore, likely to provide water safe for human consumption and household use, such as piped water supplies into the house, yard, boreholes or protected wells or springs (Jo Geere, 2016). Most unimproved sources - for example, surface water or unprotected wells or springs - and many improved water sources are located away from the home and publicly shared.

Transportation of water from the supply point to the house is, therefore, required, and globally this is most often achieved through unpaid, informal work performed by women. In developing countries, women and girls spend an estimated 40 billion hours a year collecting water.

Meanwhile, it is easy to conclude that based on the responses from households regarding the quality of drinking water not fit for human consumption. However, the respondent in four Kebele about stated that the water was colored; the water is simply not purified. To this ends, this means households had perceived all the possible combinations of negative description of the water from odour, colour, taste and particles with the almost all respondents just simply emphasizing one dominant negative property. For example in Utalo highly density suburb one respondent stated that; "If the water is collected in a container a layer of sediments settles at the bottom and cloudy water remains, this has compelled us to boil the water to make it safe for drinking."

\section{Reference}

Agriculture workshop: pastoral and agro-pastoral systems factsheet. Available at: http://

Asongu, S. (2013). Investment and Inequality in Africa: which financial channels are good for the poor? African

Finance Journal, $15(2)$ $43-65$ Retrieved

from

http://reference.sabinet.co.za/webx/access/electronic_journals/finj/finj_v15_n2_a3.pdf

Baumann, T. (2001). Microfinance and poverty alleviation in South Africa. ... Report, Bay Research and Consultancy Services ..., 4330(August). Retrieved from http://www.tanzaniagateway.org/docs/Microfinance_and_Poverty_Alleviation_in_South Africa_Baum.pdf

Benjaminsen, A., Maganga, F., Moshi, J.andAbdallah, H. (2014). The Kilosa Killlings. Political Ecology of Farmer-Herder Conflict in Tanzania. [https://www.researchgate.net/publication/230265512 The_Kilosa_Killings_Political_Ecology_of_a_Farm er-Herder_Conflict_in_Tanzania]site visitedon 27/06/2016.

Blench R (2001) 'You can't go home again': pastoralism in the new millennium. FAO report 
Brookes JD Goal 6-Rising to the Challenge: Enabling Access to Clean and Safe Water Globally. Available online: https://unchronicle.un.org/article/goal-6-rising-challenge-enabling-access-clean-and-safe-water-globally (accessed on 18 December 2017).

Burgsdorff, D. Von. (2010). the South Africa-Zimbabwe Remittance Corridor: An Analysis of Key Drivers and Constraints. Retrieved from http://uctscholar.uct.ac.za/PDF/57658 Von Burgsdorff, D.pdf

Carney, D. (1998). Implementing the Sustainable Rural Livelihoods Approach. In Sustainable Rural Livelihoods: What Contributions Can We Make?, edited by Diane Carney (1992).

Chibba, M. (2009). Financial inclusion, poverty reduction and the millennium development goals. European $\begin{array}{lllll}\text { Journal of Development } & \text { Research. } & \text { Retrieved }\end{array}$ http://www.palgravejournals.com.ezproxy.uct.ac.za/ejdr/journal/v21/n2/abs/ejdr2008117a.html

CSA, 2007. Central Statistical Authority population estimates, Ethiopia, Addis Ababa

DFID, 2000. Sustainable Rural Livelihoods Guidance Sheet, London, UK

Diouf K; Tabatabai P; Rudolph J; Marx M Diarrhoea prevalence in children under five years of age in rural Burundi: An assessment of social and behavioural factors at the household level. Glob. Health Action 2014, 7, 24895. [PMC free article] [PubMed] [Google Scholar]

Ellis, F., and Allison, E., 2004. Livelihood diversification and natural resource access: Overseas Development Group Working paper 9. University of East Anglia UK.

Ezeh OK; Agho KE; Dibley MJ; Hall J; Page AN The Impact of Water and Sanitation on Childhood Mortality in Nigeria: Evidence from Demographic and Health Surveys, 2003-2013. Int. J. Environ. Res. Public Health 2014, 11, 9256-9272. [PMC free article] [PubMed] [Google Scholar]

FAO (2001) Pastoralism in the new millennium. Animal production and health paper no 150. UN Food and Agriculture Organization, Rome

FAO (2002) Cattle and small ruminant systems in sub-Saharan Africa: a systematic review. Available at: $\mathrm{ftp}: / / \mathrm{ftp}$.fao.org/docrep/fao/005/y4176E/y4176E00.pdf

Fratkin, E.(2001). East African Pastoralism in Transition: Maasai, Borana, and Rendille Cases. African Studies Review, Vol. 44, No. 3 (Dec., 2001), pp. 1-25. African Studies Association.

Hutton G; Chase C the Knowledge Base for Achieving the Sustainable Development Goal Targets on Water Supply, Sanitation and Hygiene. Int. J. Environ. Res. Public Health 2016, 13, 536. [PMC free article] [PubMed] [Google Scholar]

IFAD (2008) Livestock and pastoralists. Available at: http://www.ifad.org/lrkm/factsheet/pastoralists.pdf

Lagarde, C. (2014). Empowerment through financial inclusion. In International Forum for Financial Inclusion (pp. 1-8).

Lavers, T. (2011). The role of foreign investment in Ethiopia's smallholder agricultural development strategy R. Pointer.

Lo Storto, C.; Goncharuk, A.G. Efficiency vs effectiveness: A benchmarking study on European healthcare systems. Econ. Sociol. 2017, 10, 102-115. [CrossRef] [PubMed]

Norman, A.S. (2013). Challenges of managing elections in Africa.ZENITH International Journal of Business Economics andManagement Research3 (5): 001-007.

O’Neil D (2011) Pastoralism. http://anthro.palomar.edu/subsistence/sub_3.htm

Oromo study association annual Conference University of Minnesota, USA, on $14^{\text {th }}-15^{\text {th }}$ July 2012

Primary health care report of the International Conference on Primary Health Care, Alma-Ata, USSR, 6-12 September 1978/ jointly sponsored by the World Health Organization and the United Nations Children's Fund. Geneva: World Health 1978. (http://www.who.int/publications/almaata declaration en.pdf,accessed 15 October 2018).

Tavanti, M. (2013). Before microfinance: the social value of microsavings in Vincentian poverty reduction. Journal of Business Ethics. Retrieved http://link.springer.com.ezproxy.uct.ac.za/article/10.1007/s10551-012-1566-1

UNDP. (2012). Decent work country programme for Zimbabwe.

USAID (2011) Comprehensive Africa Agriculture Development Programme (CAADP) climate smart

USAID 2011. Climate Change and Conflict in Pastoralist Regions of Ethiopia: Mounting Challenges, Emerging Responses-CMM Discussion Paper No.4

Vermeulen, S. and L. Cotula (2010). Making the most of agricultural investment: A survey of business models that provide opportunities for smallholders. London/Rome/Bern, IIED/FAO/IFAD/SDC.

WWAP (World Water Assessment Programme). The United Nations World Water Development Report 2015 : Water for a Sustainable World; WWAP: Paris, France, 2015. [Google Scholar]

www.caadp.net/pdf/1a.\%20Pastoral\%20and\%20Agropastoral\%20systems $\% 20$ facthseet.pdf 